\title{
Primary "Empty Sella" in Adults: Endocrine Findings
}

\author{
P. DEL MONTE, L. FOPPIANI, C. CAFFERATA*, A. MARUGO AND D. BERNASCONI \\ Division of Endocrinology, Galliera Hospital, Genoa 16128, Italy \\ *Laboratory of Nuclear Medicine, Galliera Hospital, Genoa 16128, Italy
}

\begin{abstract}
Increasing evidence of impaired pituitary function in many subjects with primary empty sella (PES) has been reported. We conducted a retrospective analysis of our patients with PES, in order to ascertain presenting symptoms and endocrine status on diagnosis and during follow-up. Magnetic resonance imaging (MRI) of the pituitary leading to the diagnosis of PES was performed in 8 patients $(5 \mathrm{~F}$ and $3 \mathrm{M}$, age: $60.1 \pm 3.3$ years, $\mathrm{M} \pm \mathrm{SE}$; group 1$)$ after the diagnosis of global anterior hypopituitarism $(\mathrm{H})$, and in 20 patients $(\mathrm{F}$, age $56.9 \pm 2.2$ years, group 2) for other clinical reasons. Baseline determinations of pituitary and target gland hormones and of IGF-I were performed. GH response to GHRH plus arginine stimulation was also evaluated. Ten age- and BMI-matched subjects (7 F, $3 \mathrm{M}$, age: $53.0 \pm 4.0$ years) with normal pituitary function served as controls (C). In group 1, the presenting symptoms leading to the diagnosis of $\mathrm{H}$ were consciousness disturbances, hyponatremia and chronic fatigue. The $\mathrm{GH}$ response to stimulation was absent (peak:1.0 $\pm 0.3 \mathrm{ng} / \mathrm{ml})$ and IGF-I levels $(60.1 \pm 9.3 \mathrm{ng} / \mathrm{ml})$ were significantly lower $(\mathrm{p}<0.001)$ than in C and group 2 PES patients. Among group 2 PES patients, the main presenting symptoms were headache and visual alterations. Baseline hormone levels proved normal in 17 subjects, while slight hyperprolactinemia was observed in 2 and hypogonadotropic hypogonadism in one. The GH response to stimulation $(12.9 \pm 3.4 \mathrm{ng} / \mathrm{ml})$ and IGF-I levels $(141.7 \pm 12.0 \mathrm{ng} / \mathrm{ml})$ were lower $(\mathrm{p}<0.05)$ than in $\mathrm{C}(\mathrm{GH}: 33.4 \pm 8.8 \mathrm{ng} / \mathrm{ml}$, IGF-I: $193.1 \pm 20.3 \mathrm{ng} / \mathrm{ml})$. PES is a heterogeneous condition that ranges from hypopituitarism to various degrees of isolated GH deficiency, and which needs careful endocrine assessment, treatment and follow-up.
\end{abstract}

Key words: Empty sella, Hypopituitarism, GH deficiency

(Endocrine Journal 53: 803-809, 2006)

THE term "primary empty sella" (PES) refers to a neuroradiological entity characterised by a cerebrospinal fluid-filled sella, with a small pituitary gland compressed to the rim of the fossa, in the absence of either other pathological processes or a history of previous pituitary surgery, radiotherapy or apoplexy. While its etiology is not completely clear, it is currently viewed as being related to the mechanical transmission of the cerebrospinal fluid pressure through an incomplete sellar diaphragm. PES has been reported in $6-20 \%$ of unselected autopsies [1]. Furthermore, owing to the widespread use of computed tomography (CT) and

Received: February 2, 2006

Accepted: August 8, 2006

Correspondence to: Patrizia DEL MONTE, M.D., Ph.D., Division of Endocrinology, Galliera Hospital, Mura delle Cappuccine 14, 16128 Genoa, Italy magnetic resonance imaging (MRI) techniques, PES has become a frequent "incidental" finding. This condition is more common in women and is frequently associated with obesity, hypertension, headache and nonspecific visual alterations. More rarely, PES patients present with CSF rhinorrhea, visual field defects or papilledema. Previous studies have reported preserved normal pituitary function in most PES cases; partial or total hypopituitarism, however, has been described in about $25 \%$ of patients and hyperprolactinemia due to distortion of the pituitary stalk in about $10 \%$ [2-5]. GH deficiency was described in early reports [6-8] and more recent studies have demonstrated a decreased pituitary GH reserve in $35-60 \%$ of adult PES subjects [9-11].

We report our experience in a cohort of 28 adult patients with PES, 8 of whom presented with symptoms of global anterior hypopituitarism $(\mathrm{H})$, while 20 con- 
stituted a consecutive series of patients in whom the diagnosis of PES was made on MRI performed for other medical reasons, in order to ascertain presenting symptoms and endocrine status on diagnosis and during follow-up.

\section{Subjects and Methods}

\section{Subjects}

Contrast MRI of the pituitary region was performed in 8 patients after the diagnosis of global anterior hypopituitarism (H) (group 1: 5 females $(\mathrm{F})$ and 3 males (M), age: $60.1 \pm 3.3$ years, BMI: $26.2 \pm 1.2 \mathrm{~kg} / \mathrm{m}^{2}$, $\mathrm{M} \pm \mathrm{SE}$ ). In six patients, $\mathrm{H}$ was previously unrecognized, while two were already on substitutive treatment and one of these had diabetes insipidus. The clinical presentation of group 1 patients is described in Table 1.

In a series of 20 consecutive patients (group 2: $\mathrm{F}$, age $56.9 \pm 2.2$ years, BMI: $30.0 \pm 1.3 \mathrm{~kg} / \mathrm{m}^{2}, \mathrm{M} \pm \mathrm{SE}$ ) PES was diagnosed on MRI performed during the diagnostic work-up for other medical reasons: headache in 10 , visual alterations in 5 , slight hyper-prolactinemia

Table 1. Clinical data of group 1 PES patients with global anterior hypopituitarism

\begin{tabular}{|c|c|c|}
\hline & Presenting symptoms & Clinical data \\
\hline $\mathrm{F}, 62 \mathrm{yrs}$ & $\begin{array}{l}\text { Hospitalized for } \\
\text { lethargy, hypotension, } \\
\text { nausea, back pain }\end{array}$ & $\begin{array}{l}\text { Hyponatremia, anemia, } \\
\text { osteoporotic vertebral } \\
\text { fractures }\end{array}$ \\
\hline F, 53 yrs & $\begin{array}{l}\text { Hospitalized for } \\
\text { lethargy, congestive } \\
\text { heart failure, nausea }\end{array}$ & $\begin{array}{l}\text { Hyponatremia, anemia, } \\
\text { pericardial effusion }\end{array}$ \\
\hline M, 67 yrs & $\begin{array}{l}\text { Hospitalized for } \\
\text { confusion, severe } \\
\text { fatigue, depression }\end{array}$ & $\begin{array}{l}\text { Ischemic } \\
\text { cerebrovascular disease, } \\
\text { ischemic cardiopathy }\end{array}$ \\
\hline M, 52 yrs & $\begin{array}{l}\text { Hospitalized for } \\
\text { congestive heart failure, } \\
\text { hypertension }\end{array}$ & $\begin{array}{l}\text { Type } 2 \text { diabetes } \\
\text { mellitus, severe mixed } \\
\text { dyslipidemia }\end{array}$ \\
\hline F, 64 yrs & $\begin{array}{l}\text { Worsening fatigue, } \\
\text { coldness, muscular pain }\end{array}$ & $\begin{array}{l}\text { Anemia, dyslipidemia, } \\
\text { increased CPK levels }\end{array}$ \\
\hline $\mathrm{F}, 42 \mathrm{yrs}$ & $\begin{array}{l}\text { Nausea, worsening } \\
\text { fatigue, secondary } \\
\text { amenorrhea }\end{array}$ & $\begin{array}{l}\text { Mixed dyslipidemia, } \\
\text { eosinophilia }\end{array}$ \\
\hline M, 49 yrs & Diabetes Insipidus & $\begin{array}{l}\text { Already on treatment } \\
\text { for global anterior } \\
\text { hypopituitarism }\end{array}$ \\
\hline F, 54 yrs & $\begin{array}{l}\text { Rhinoliquorrea, visual } \\
\text { alterations }\end{array}$ & $\begin{array}{l}\text { Already on treatment } \\
\text { for global anterior } \\
\text { hypopituitarism }\end{array}$ \\
\hline
\end{tabular}

and menstrual alterations in 2, previous surgery for rhinoliquorrhea in one, transient ischemic attack and dizziness in 2. Eight of these patients were on appropriate treatment for primary overt $(\mathrm{n}=3)$ or subclinical $(\mathrm{n}=5)$ hypothyroidism. Antithyroid antibodies were positive in six. Ten patients were hypertensive and 4 had impaired fasting glucose, while cholesterol levels were increased in 13

Neuroradiological studies revealed a total empty sella (more than $50 \%$ of the sella filled with CSF and pituitary gland thickness $\leq 2 \mathrm{~mm}$ ) in all patients. No patient had a history of pituitary tumour, local surgery or irradiation, an expanded fossa or other morphological features suggesting a possible auto-infarction of a previously undetected pituitary tumour.

A group of 10 subjects $(7 \mathrm{~F}, 3 \mathrm{M}$, age $53.0 \pm 4.0$ years, BMI: $30.1 \pm 2.4 \mathrm{~kg} / \mathrm{m}^{2}, \mathrm{M} \pm \mathrm{SE}$ ) with normal pituitary function served as controls $(\mathrm{C})$. All subjects gave their written informed consent.

\section{Methods}

Magnetic resonance imaging (MRI), before and after gadolinium administration, or both computed tomography (CT) and MRI were performed in 27 patients, while only CT was performed in a patient in whom MRI was contraindicated. All patients underwent ophthalmologic examination. Baseline endocrine evaluations (fasting morning serum $\mathrm{LH}, \mathrm{FSH}$, prolactin, ACTH, cortisol, FT3, FT4, TSH, IGF-I, $17 \beta$-estradiol, testosterone and 24-h free-urinary cortisol) and $\mathrm{GH}$ response to GHRH plus arginine stimulation (baseline $\mathrm{GH}$ levels alone not being diagnostic for $\mathrm{GH}$ deficiency) were performed in every patient. Blood samples were drawn at the baseline and 15, 30,60 and $90 \mathrm{~min}$ after the administration of GHRH1-29 $(1 \mu \mathrm{g} / \mathrm{kg}$ b.w. i.v.; GEREF, Serono, Rome, Italy) plus Arginine hydrochloride $(0.5 \mathrm{~g} / \mathrm{kg}$ b.w. i.v., L. Monico, VeneziaMestre, Italy). Other appropriate stimulation tests (TRH, Ferring, Germany, $200 \mu \mathrm{g}$ bolus i.v. with blood samples for TSH drawn at 0, and 15, 30, 60 min after stimulation; LHRH, Ferring, Germany, $100 \mu \mathrm{g}$ bolus i.v. with blood samples for LH and FSH drawn at 0 , and $15,30,60,90 \mathrm{~min}$ after stimulation) were performed when needed.

Serum hormone levels were measured by IRMA or RIA assays using commercially available kits. Specifically, GH was measured by IRMA (Radim, Rome, Italy); the sensitivity of the assay was $0.04 \mathrm{ng} / \mathrm{ml}$ and 
the intra- and inter-assay coefficients of variation were between 2.4 and $5 \%$. Serum total IGF-I was determined by radioimmunoassay (Adaltis, Bologna, Italy), after acid-ethanol extraction, to avoid binding protein interference. The sensitivity of the assay was $1 \mathrm{ng} / \mathrm{ml}$. The intra- and inter-assay coefficients of variation were between $3 \%$ and $7 \%$.

Serum GH peak $<9 \mathrm{ng} / \mathrm{ml}$ after GHRH plus arginine stimulation was considered indicative of GH deficiency, in accordance with the literature cut-off [12].

Statistical analysis was performed by means of Mann-Whitney U-test for unpaired data, and correlation analysis was performed by means of Spearman's rank order test. Data were expressed as mean \pm SEM.

\section{Results}

\section{Group 1}

In group 1, $\mathrm{H}$ was diagnosed in 4 patients after hospitalization for severe worsening of health conditions ( 2 for consciousness disturbances and hyponatremia, two for congestive heart failure, anemia and depression). In 2 subjects, the diagnosis of $\mathrm{H}$ was made during clinical investigation for chronic fatigue and anemia, while 2 were already on treatment for $\mathrm{H}$ and one of these had developed diabetes insipidus (Table 1).

In these 8 patients, CT/MRI evidenced a complete empty sella, in the absence of signs of previously undiagnosed pituitary tumours or infarction or other morphological alterations. Ophthalmological findings were normal. Morning serum cortisol was $<1 \mu \mathrm{g} / \mathrm{dl}$, with ACTH levels $<5 \mathrm{pg} / \mathrm{ml}$; FT3 and FT4 values were reduced, with normal-low TSH levels; LH and FSH were inappropriately low for age in females, whereas in males they were associated to very low testosterone levels. The GH response to stimulation in this group was absent (peak: $1.0 \pm 0.3 \mathrm{ng} / \mathrm{ml}$ ) and IGF-I levels were significantly $(\mathrm{p}<0.001)$ reduced $(60.1 \pm 9.3 \mathrm{ng} /$ $\mathrm{ml}$ (Fig. 1,2) in comparison with both $\mathrm{C}$ and group 2 PES patients. Due to the virtual absence of GH response to stimulation a correlation with BMI could not be assessed in this group of patients.

All group 1 patients greatly improved on substitutive hormone treatment with glucocorticoids, L-thyroxine and, in men, testosterone. One patient was started on DDAVP treatment for central diabetes insipidus. Seven were put on GH replacement therapy (mean dose
$0.3 \mathrm{mg} /$ day), which further improved their wellbeing; one patient refused this therapy on account of the daily injections needed. All patients remained in satisfactory clinical and hormonal control during follow-up (range 4-10 years).

\section{Group 2}

In group 2 PES patients, the presenting symptoms that prompted the neuroradiological studies were: headache $(n=10)$, visual alterations $(n=5)$, slight hyperprolactinemia and menstrual alterations $(n=2)$, rhinoliquorrea $(n=1)$, transient ischemic attacks and dizziness $(n=2)$. Eighteen women had experienced normal childbirth, thirteen had entered menopause at a normal age, one had premature ovarian failure, one was affected by primary amenorrhea, primary hypothyroidism and deafness, and 5 had regular menses. Ten patients were hypertensive and 4 had impaired fasting glucose, while cholesterol levels were increased in 13 . BMI was indicative of overweight-obesity in $75 \%$ of patients. CT/MRI revealed a complete empty sella, without other alterations.

Baseline endocrine evaluations proved normal in 17 subjects, while slight hyperprolactinemia (40-60 ng/ $\mathrm{ml}$ ) was observed in 2, which normalized on low-dose cabergoline treatment; low gonadotropins, unresponsive to LHRH stimulation, were observed in the patient with primary amenorrhea.

The $\mathrm{GH}$ peak $(12.9 \pm 3.4 \mathrm{ng} / \mathrm{ml}, \mathrm{M} \pm \mathrm{SE})$ in response to stimulation was lower $(\mathrm{p}<0.05)$ than in $\mathrm{C}$ $(33.4 \pm 8.8 \mathrm{ng} / \mathrm{ml})$ (Fig. 1). In particular, 13 out of 20 patients showed a GH peak $<9 \mathrm{ng} / \mathrm{ml}$, which is diagnostic for severe GH deficiency according to the literature cut-off [12]. A negative correlation between GH peak and BMI was observed in both group 2 PES $(\mathrm{r}=-0.5$, $\mathrm{p}=0.01)$ and normal subjects $(\mathrm{r}=-0.7, \mathrm{p}<0.05)$. Whether specific BMI-related cut-off limits for GH response to GHRH plus arginine stimulation were considered, 8 patients still showed peak values diagnostic for GH deficiency according to the literature [13].

IGF-I levels $(141.7 \pm 12.0 \mathrm{ng} / \mathrm{ml})$ were reduced $(\mathrm{p}<0.05)$ in comparison with $\mathrm{C}(193.1 \pm 20.3 \mathrm{ng} / \mathrm{ml})$ (Fig. 2). No correlation was evidenced between GH response to stimulation and age, or between IGF-I levels and GH peak or BMI.

Eight women in group 2 were on appropriate treatment for primary subclinical or overt hypothyroidism, and signs of thyroid autoimmunity were detected in six. 
Two patients were on L-thyroxine for nodular goiter. In another 10 patients, thyroid function and morphology were normal, without signs of thyroid autoimmunity, and TSH was highly responsive to TRH stimulation (baseline: $2.4 \pm 0.3$; $+30 \mathrm{~min}$ : $16.0 \pm 3.4$; $+60 \mathrm{~min}$ : $13.0 \pm 2.2 \mu \mathrm{U} / \mathrm{ml})$.

Adrenal function proved normal in all group 2 subjects. No further endocrine deficiencies or neuroradiological modifications were detected during follow-up (range 3-8 years).

\section{Discussion}

Our data underline the fact that the development of hypopituitarism often goes unrecognized in patients with PES, and that the diagnosis may be delayed. Indeed, it is noteworthy that four out of eight $(50 \%) \mathrm{H}$ patients were admitted to hospital in life-threatening conditions related to previously undiagnosed secondary hypoadrenalism and hypothyroidism. Two of these suffered from alterations in consciousness and severe hyponatremia, which resolved after glucocorticoid substitution. Recent studies have reported that hypopituitarism, including secondary adrenal insufficiency, is a frequently overlooked cause of severe hyponatremia [14-16]. In particular, in the series reported by Diederich et al. [14], 20\% of patients with severe normovolemic hyponatremia were suffering from previously unrecognised hypopituitarism and secondary adrenal insufficiency, mostly due to empty sella (43\%), Sheehan's syndrome and pituitary tumours. In our patients, hypothyroidism contributed to neurological and muscular alterations and to anemia. Anemia is a frequent finding in hypopituitarism; hydrocortisone and levothyroxine treatment increase hemoglobin levels in most patients and additional replacement therapy with androgen and $\mathrm{GH}$ yields further improvement [17]. As expected, all $\mathrm{H}$ patients displayed low IGF-I levels, and none showed any $\mathrm{GH}$ response to stimulation. GH deficiency probably played a role in the reduction of cardiac performance [18-22], as well as in the osteoporosis, dyslipidemia and depression [23-25] found in these patients. GH replacement therapy improved their quality of life. The relatively high percentage of $\mathrm{H}$ in our PES series (28\%) may represent an ascertainment bias, considering that these patients are more likely to come to medical attention because of their severely impaired clinical condition. It is conceivable that the impairment of pituitary function might have developed gradually, as supported by the finding of normal menopausal age in most $(80 \%)$ women in this group. The neuroradiological image of an empty sella might constitute a common final result of different processes (vascular, autoimmune, genetic) leading to a progressive hypotrophy of the pituitary. Furthermore, an increase in intrasellar pressure, causing enduring compression of the normal pituitary tissue and stalk distortion, might have led to functional insufficiency of the pituitary cells and interfered with the normal transmission of hypothalamic signals.

In group 2 PES patients, headache and visual alterations were the two main reasons for neuroradiological study. It is noteworthy that all these patients were women, confirming a strong sex-related prevalence of this condition. Overweight, hypertension and dyslipidemia were frequently observed, whereas menopause occurred at normal age in most cases. Our data confirm that impaired GH secretion is frequent in PES, even in the absence of other pituitary hormone alterations, as reported in other studies [9-11]. Indeed, 65\% of group 2 PES subjects showed a post-stimulation GH peak diagnostic for GH deficiency. The mechanism underlying isolated GH deficiency in PES subjects is not yet clear; it is well known, however, that $\mathrm{GH}$ is the most vulnerable pituitary hormone and that its secretion is disturbed very early in the case of damage to the pituitary gland; this is in agreement with the fact that somatotrophe cells account for up to $50 \%$ of the normal pituitary gland volume. It has also been suggested that the anatomical distribution of $\mathrm{GH}-$ secreting cells within the pituitary gland makes these cells more vulnerable. On the other hand, it may also be hypothesised that the somatotrophe cells and/or the neuro-regulatory mechanisms of GH secretion may be particularly sensitive to increased intrasellar pressure. A negative correlation between GH peak and BMI was observed in both group 2 PES subjects and in controls, confirming that obesity "per se" can reduce GH reserve $[26,27]$. However, using specific BMI-related cut-off limits for GH response [13], we found that $40 \%$ of group 2 PES subjects still showed peak values diagnostic for GH deficiency.

Furthermore, the magnitude of the impairment in $\mathrm{GH}$ response, together with the fact that IGF-I levels were reduced in comparison with age- and weight- matched controls, supports the presence of an alteration in the regulation of GH secretion in several PES subjects. 
An impairment in GH secretion might also play a role in the development of obesity; a reduction in daily GH production rate in obesity [28] and an inverse correlation between truncal fat and mean 24-h GH have been recently reported [29].

In any case, the GH deficiency was far less profound in PES patients with isolated GH deficiency than in PES patients with global anterior hypopituitarism, as evidenced both by the difference in GH response to stimulation and by IGF-I levels (Fig. 1,2).

Whether group 2 PES patients could be candidate to GH replacement therapy is matter of debate. So far, only two patients in this group have been treated; they had very low GH response to testing associated with reduced IGF-I levels and osteoporosis and showed an improvement in quality of life during treatment. No additional deficiencies of pituitary hormones occurred during the follow-up in PES 2 patients and no significant variations in IGF-I levels were observed. A GH reserve re-testing over time, possibly after weight loss in overweight subjects, seems to be advisable in this group. The indications for treatment should follow the criteria suggested in the more recent guidelines on evaluation and treatment of adult growth hormone deficiency [30].

Slight hyperprolactinemia was the second most common alteration found in group 2 PES, followed by hypogonadotropic hypogonadism, while no alterations in the pituitary-adrenal axis were observed.

An intriguing feature of our group 2 PES patients was the high prevalence $(40 \%)$ of primary thyroid dysfunction, both overt and sub-clinical, with signs of thyroid autoimmunity in one-third of patients. The association between primary thyroid diseases and PES has been reported by other authors [31,32]. This is an interesting point, as in some cases PES may be the result of an autoimmune process involving the pituitary gland. A recent study, however, suggests that autoimmunity does not play a major role in the pathogenesis of PES syndrome [33]. Furthermore, in our study a subgroup of PES patients with normal thyroid function and morphology and without signs of thyroid autoimmunity displayed an increased TSH response to TRH

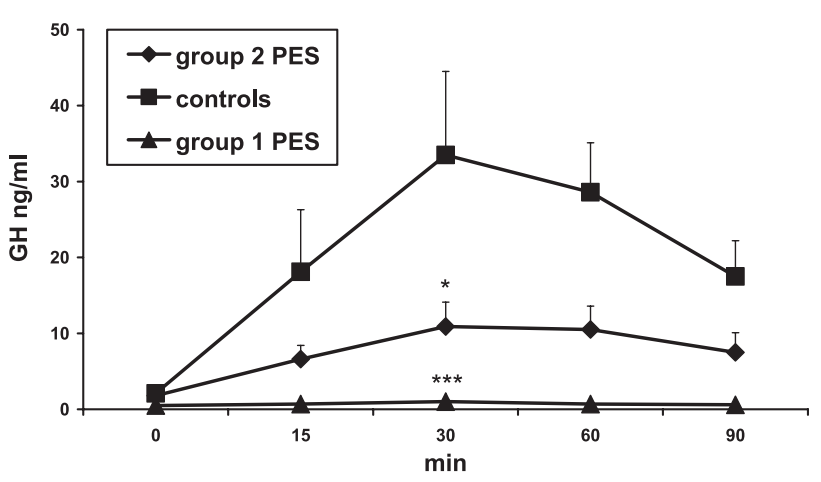

Fig. 1. $\mathrm{GH}$ response $(\mathrm{M} \pm \mathrm{SEM})$ to $\mathrm{GHRH}+$ Arginine in controls, group $1(* * * \mathrm{p}<0.001$ vs controls and vs group 2 PES patients) and group 2 PES patients $\left({ }^{*} \mathrm{p}<0.05\right.$ vs controls).

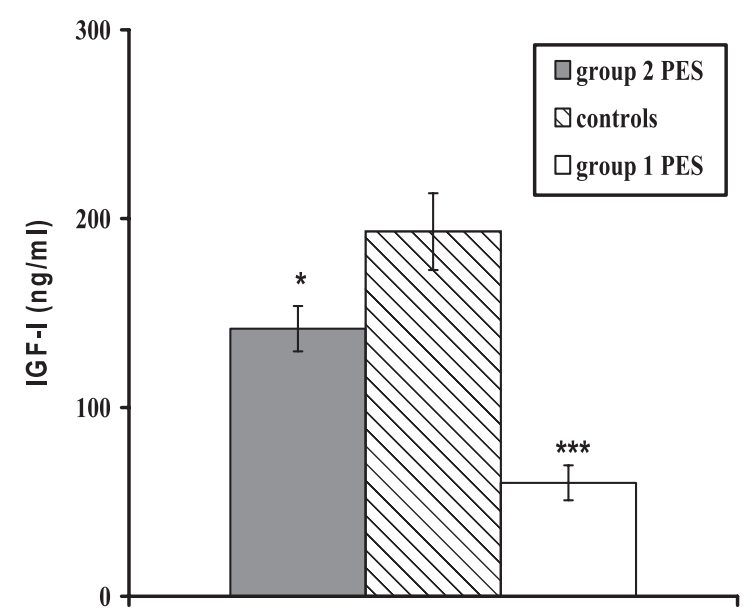

Fig. 2. IGF-I concentrations $(\mathrm{M} \pm \mathrm{SEM})$ in group 1 $(* * * p<0.001$ vs controls and group 2 PES) and group 2 PES patients $\left({ }^{*} \mathrm{p}<0.05\right.$ vs controls), and in normal ageand BMI-matched controls.

stimulation; this suggests a possible central alteration in the neuroregulation of TSH secretion, as already reported [10].

In conclusion, PES is a multifaceted condition that ranges from global hypopituitarism to various degrees of isolated GH deficiency. This probably reflects heterogeneity in the pathogenesis of the disease. It therefore seems that PES patients deserve thorough endocrine evaluation, treatment and long-term follow-up.

\section{References}

1. Bjerre P (1990) The empty sella. A reappraisal of etiology and pathogenesis. Acta Neurol Scand (Supp 1) 130:
$1-25$.

2. Gharib H, Frey HM, Laws ER Jr, Randall RV, 
Scheithauer BW (1983) Coexistent primary empty sella syndrome and hyperprolactinemia. Report of 11 cases. Archiv Intern Med 143: 1383-1386.

3. Buchfelder M, Brockmeier S, Pichl J, Screll U, Fahlbusch R (1989) Results of dynamic endocrine testing of hypothalamic pituitary function in patients with a primary empty sella syndrome. Horm Metab Res 21: 573-576.

4. Gallardo E, Schacter D, Caceres E, Becker P, Colin E, Martinez C, Henriquez C (1992) The empty sella: results of treatment in 76 successive cases and high frequency of endocrine and neurological disturbances. Clin Endocrinol (Oxford) 37: 529-533.

5. Santeusanio F (2002) GH and primary empty sella. $J$ Endocrinol Invest 25: 574-575.

6. Faglia G, Ambrosi B, Beck-Peccoz P, Giovannelli M (1973) Disorders of growth hormone and corticotropin regulation in patients with empty sella. J Neurosurg: 38: 59-64.

7. Pocecco M, De Campo C, Marinoni S, Tommasini G, Basso T, Muzzolini C, Sacher B (1989) High frequency of empty sella syndrome in children with growth hormone deficiency. Helv Pediatr Acta 43: 295-301.

8. Cacciari E, Zucchini S, Ambrosetto P, Tani G, Carla G, Cicognani A, Pirazzoli P, Sganga T, Balsamo A, Cassio A, et al. (1994) Empty sella in children and adolescents with possible hypothalamic-pituitary disorders. J Clin Endocrinol Metab: 84: 1277-1282.

9. Gasperi M, Aimaretti G, Cecconi E, Colao A, Di Somma C, Cannavò S, Baffoni C, Cosottini M, Curtò L, Trimarchi F, Lombardi G, Grasso L, Ghigo E, Martino E (2002) Impairment of GH secretion in adults with primary empty sella. J Endocrinol Invest 25: 329333.

10. Cannavò $\mathrm{S}$, Curtò L, Venturino $\mathrm{M}$, Squadrito $\mathrm{S}, \mathrm{Al}$ Moto B, Narbone MC, Rao R, Trimarchi F (2002) Abnormalities of hypothalamic-pituitary-thyroid axis in patients with primary empty sella. J Endocrinol Invest 25: 236-239.

11. De Marinis L, Bonadonna S, Bianchi A, Maira G, Giustina A (2005) Extensive clinical experience: Primary empty sella. J Clin Endocrinol Metab 90: 54715477.

12. Aimaretti G, Corneli G, Razzore P, Baffoni C, Arvat E, Camanni F, Ghigo E (1998) Comparison between insulin-induced hypoglycemia and growth hormone(GH)releasing hormone+arginine as provocative tests for the diagnosis of GH deficiency in adults. J Clin Endocrinol Metabol 83: 1615-1618.

13. Corneli G, Di Somma C, Balzelli R, Rovere S, Gasco V, Croce CG, Grottoli S, Maccario M, Colao A, Lombardi G, Ghigo E, Camanni F, Amaretto G (2005) The cut-off limits of the GH response to GH-releasing hormone-arginine test related to body mass index. Eur J Endocrinol 153: 257-264.
14. Diederich S, Franzen NF, Bahr V, Oelkers W (2003) Severe hyponatremia due to hypopituitarism with adrenal insufficiency: report on 28 cases. Eur J Endocrinol 148: 609-617.

15. Chanson P (2003) Severe hyponatriemia as a frequent revealing sign of hypopituitarism after 60 years of age. Eur J Endocrinol: 149: 177-178.

16. Olchovski D, Ezra D, Vered I, Hadani M, Shimon I (2005) Symptomatic hyponatriemia as presenting sign of hypothalamic-pituitary disease: a syndrome of inappropriate secretion of antidiuretic hormone (SIADH)like glucocorticosteroid responsive condition. $J$ Endocrinol Invest 28: 151-156.

17. Nishioka H, Haraoka J (2005) Hypopituitarism and anemia: effect of replacement therapy with hydrocortisone and/or levothyroxine. J Endocrinol Invest: 28: 528-533.

18. Amato A, Carella C, Fazio S, LaMontagna G, Cittadini A, Sabatini D, Marciano Mone C, Sacca L, Bellastella A (1993) Body composition, bone metabolism, and heart structure and function in growth hormone (GH)deficient adults before and after GH replacement therapy at low doses. J Clin Endocrinol Metab 77: 16711676.

19. Merola B, Cittadini A, Colao A, Longobardi S, Fazio S, Sabatini D, Sacca L, Lombardi G (1993) Cardiac structural and functional abnormalities in adult patients with growth hormone deficiency. J Clin Endocrinol Metab 77: 1658-1671.

20. De Boer H, Block G, van der Veen EA (1995) Clinical aspects of growth hormone deficiency in adults. Endocr Rev 16: 63-86.

21. Carroll PV, Christ ER, Bengtsson BA, Carlsson L, Christiansen JS, Clemmons D, Hintz R, Ho K, Laron Z, Sizonenko P, Sonksen PH, Tanaka T, Thorner M (1998) Growth hormone deficiency in adulthood and the effects of growth hormone replacement. A review. $J$ Clin Endocrinol Metab 83: 382-395.

22. Colao A, Cuocolo A, Di Somma C, Cerbone G, Della Morte AM, Nicolai E, Lucci R, Salvatore M, Lombardi $\mathrm{G}$ (1999) Impaired cardiac performance in elderly patients with growth hormone deficiency. J Clin Endocrinol Metab 84: 3950-3955.

23. Colao A, Cerbone G, Pivonello R, Amaretti G, Loche S, Di Somma C, Cerbone G, Faggiano A, Corneli G, Ghigo E, Lombardi G (1999) The growth hormone (GH) response to arginine plus GH-releasing hormone test is correlated to the severity of lipid profile abnormalities in adult patients with GH deficiency. J Clin Endocrinol Metab 84: 1277-1282.

24. Colao A, Di Somma C, Pivonello R, Loche S, Amaretti G, Faggiano A, Corneli G, Ghigo E, Lombardi G (1999) Bone loss is correlated to the severity of growth hormone deficiency in adult patients with hypopituitarism. J Clin Endocrinol Metab 84: 1919-1924. 
25. Murray RD, Skillicorn FJ, Howell SJ, Lissett CA, Rahim A, Smethurst LE, Shalet SM (1999) Influences on quality of life in GH-deficient adults and their effect on response to treatment. Clin Endocrinol (Oxford) 52: 537-542.

26. Ghigo E, Procopio M, Boffano GM, Arvat E, Valente F, Maccario M, Mazza E, Camanni F (1992) Arginine potentiates but does not restore the growth hormone response to growth hormone releasing hormone in obesity. Metabolism 41: 560-563.

27. Scacchi M, Pincelli AI, Cavagnini F (1999) Growth hormone in obesity. Int J Obes Relat Metab Disord 23: 260-261.

28. Gola M, Bonadonna S, Doga M, Mazziotti G, Giustina A (2005) Cardiovascular risk in aging and obesity: is there a role for GH? J Endocrinol Invest 28: 759-767.

29. Miller KK, Biller BM, Lipman JG, Bradwin G, Rifai N, Klibanski A (2005) Truncal adiposity, relative growth hormone deficiency, and cardiovascular risk. $J$
Clin Endocrinol Metab 90: 768-774.

30. Molitch ME, Clemmons DR, Malozowsky S, Merriam GR, Shalet SM, Vance ML for the Endocrine Society's Clinical Guidelines Subcommittee (2006) Evaluation and treatment of adult growth hormone deficiency: an Endocrine Society clinical practice guideline. J Clin Endocrinol Metab 91: 1621-1634.

31. Luboshitzky R, Barzilai D (1981) Primary empty sella syndrome and hypopituitarism associated with primary hypothyroidism. J Endocrinol Invest 4: 213-216.

32. La Franchi SH, Hanna CE, Krainz PL (1986) Primary hypothyroidism, empty sella and hypopituitarism. $J$ Pediatr 108: 571-573.

33. Bensing S, Rorsman F, Crock P, Sanjeevi C, Ericson K, Kampe O, Brismar K, Hulting AL (2004) No evidence for autoimmunity as a major cause of the empty sella syndrome. Exp Clin Endocrinol Diab 112: 231235 . 